DOI: https://doi.org/10.32839/2304-5809/2021-3-91-14

УДК 811.621

Лисюк А.Ю.

Київський національний університет імені Тараса Шевченка

\title{
МОРФОЛОГІЧНІ І СЕМАНТИЧНІ ОСОБЛИВОСТІ АРАБСЬКИХ ЗАПОЗИЧЕНЬ В ІНДОНЕЗІЙСЬКІЙ МОВІ
}

\begin{abstract}
Анотація. Серед найважливіших джерел мовних запозичень індонезійської мови виділяють санскрит, арабську, голландську, англійську, китайську, перську, тамільську, португальську мови, а також мову гінді та місцеві острівні мови індонезійських народностей. У статті аналізуються морфологічні і семантичні особливості арабських запозичень, як одних з найбільш численних. Розглянуто словотвірні процеси, які найчастіше використовується при утворенні арабських запозичень в індонезійській мові, а саме афріксацію. Виявлено, що у процесі афріксації відбувається додавання деривативних та фрлективних афіксів до іншомовної основи з утворенням нової граматичної і семантичної структури. Серед словотвірних афіксів індонезійської мови, які використовуються для утворення арабізмів, є: дієслівні («теN-», «-ап», «ber-», «ter-»), іменникові («se-», «-in», «-at», «peN-an», «ke-an») та прикметникові («-і», «-іah», «-ah», «-wi»). Bиокремлено три типи деорормацій значення арабських запозичень: розширення значення, звуження значення та повна розбіжність. Це зумовлено використанням арабізмів в індонезійській мові в іншій сфері застосування або асиміляцією їх значення з локальними мовними реаліями.
\end{abstract}

Ключові слова: арабські запозичення, афіксація, арабізми, мовне запозичення, арабізми.

Lysiuk Anna

Taras Shevchenko National University of Kyiv

\section{MORPHOLOGICAL AND SEMANTIC FEATURES OF ARABIC BORROWINGS IN THE INDONESIAN LANGUAGE}

Summary. Among the most important sources of Indonesian language borrowings there are Sanskrit, Arabic, Dutch, English, Chinese, Persian, Tamil, Portuguese, as well as Hindi and local island languages of Indonesian nationalities. The article analyzes the morphological and semantic features of Arabic borrowings, as one of the most numerous. The word-forming processes that are most often used in the formation of Arabic borrowings in the Indonesian language, namely affixation, are considered. It is revealed that in the process of affixation derivative and inflectional affixes are added to the foreign language base with the formation of a new grammatical and semantic structure. Among the word-forming affixes of the Indonesian language used to form Arabisms are: verbs ("meN-", "-an", "ber-", "ter-"), nouns ("se-", "-in", "-at", "peN-an", "ke-an") and adjectives ("-i", "-iah", "-ah", "-wi"). There are three types of deformations of the meaning of Arabic borrowings: expansion of meaning, narrowing of meaning and complete discrepancy. This is due to the use of Arabic in the Indonesian language in another field of application or the assimilation of their meaning with local linguistic realities. The entry of a large number of Arabic borrowings into the Indonesian language, due to long cultural contacts between the Arab and Indonesian peoples, led to the emergence of new word-forming methods in the morphology of the Indonesian language, adapted Arabic affixes, and enrichment and diversification of borrowed elements. As a result of this symbiosis, the Indonesian language has integrated a thorough layer of new concepts and realities, thus enriching its linguistic heritage. Almost every Arabic neoplasm in the Indonesian language has lost its original meaning, acquired a partially or completely new semantic color. That is why there is a need to investigate in more detail the peculiarities of the integration of Arabic in the Indonesian language, in order to better understand its lexical features.

Keywords: Arabic borrowings, affixation, Arabisms, language borrowing, Arabisms.

Постановка проблеми. Індонезійська мова та їі словниковий склад сформувались у результаті симбіозу великої кількості культур та релігій, а відповідно і їхніх мов, що історично протягом певного часу населяли або мали тісні контакти 3 територією Нусантари, сучасної Індонезії. Саме цей фокт спричинив наявність різнопланового лексичного пласту індонезійської мови, вагомою складовою якого є іншомовні запозичення. Санскрит, голландська, англійська, китайська, перська, тамільська, португальська мови, а також мова гінді та місцеві острівні мови стали багатим мовним фундаментом та культурним підѓрунтям для утворення і становлення сучасної індонезійської мови.

Однак, чи не найбільшого впливу на розвиток мови Індонезійського архіпелагу спричинили тривалі культурні контакти з арабською мовою. Торгівля, наука і релігія стали тими трьома сферами людської діяльності, де вплив арабської важко недооцінити. Таким чином, арабських пласт поступово інтегрувався у систему індонезійської мови: як повсякденної, так і мови релігії ісламу і літератури. Через словотвірні процеси і засоби арабізми поступово набули характерного для індонезійської морфології вигляду: одні зазнали повної деформації, інші - часткової, а деякі асимілювалися в оригінальному вигляді. Відповідно семантика іншомовного, запозиченого з арабської мови, словникового пласту також зазнала суттевих змін. Ледве не кожне арабське новоутворення в індонезійській мові втратило оригінальне значення, набуло частково або повністю нового семантичного забарвлення.

Саме тому виникла потреба детальніше дослідити особливості інтегрування арабізмів в індонезійську мову, задля кращого розуміння її лексичних особливостей. 
Аналіз останніх досліджень і публікацій. Проблемам аналізу і дослідження ролі та особливостей арабських мовних запозичень в індонезійській мові присвячено ряд робіт індонезійських та інших закордонних вчених, серед яких варто виділити праці Самсурі, Сібарані Р., Рускхана А. Г., Хаугена Е. та інших. На думку більшості вчених і дослідників, найпоширенішими словотвірними процесами, які беруть участь в утворенні арабізмів е: афріксація, складання основ, редуплікація, конверсія та скорочення. Однак, наприклад, Роберт Сібарані наполягає на більш детальній класифікації із виділенням таких процесів, як: внутрішня модифікація, додавання, опускання інформації, складання, виокремлення, калькування, етимологічна помилка, відхилення та утворення власних назв.

Виділення невирішених раніше частин загальної проблеми. Актуальність дослідження зумовлена тим, що морфологічні і особливо семантичні особливості арабських запозичень в індонезійській мові все ще залишаються недостатньо вивченими та дослідженими.

Мета статті. Головна мета ціеї роботи - дослідити і класифікувати способи словотвору арабських мовних запозичень в індонезійській мові, а також проаналізувати і описати можливі типи деформацій їхнього семантичного наповнення.

Виклад основного матеріалу. У сучасній Індонезії, з переважною більшістю мусульманського населення, використання арабської мови $\varepsilon$ поширеним. Більшість індонезійців не володіє арабською на розмовному рівні, однак не задумуючись використовуе слова арабського походження щодня. Список арабських запозичень Джонса 1978 року нараховуе близько 3000 слів, але вони перераховані без будь-якої інформації щодо їх джерел або періодизації.

Арабські запозичення з'являлися в індонезійській мові в різні історичні періоди, але згодом повністю зникли або перетворились у застарілу лексику. Наприклад, слово «kalam» (ручка), згадане у китайському списку арабських запозичень, було замінене португальським «репа», яке є загальновживаним до сьогодні. Велика кількість інших арабських запозичень міститься у релігійній мові індонезійських мусульман. Наприклад: «insya-Allah» (якщо на те воля Божа) i «Alhamdulillah» (хвала Богу).

Морббологічні особливості. Процес засвоення індонезійських слів з арабської мови як правило: 1) не враховуе тип слова походження; 2) передбачае наявність запозичених слів як у їх оригінальному вигляді, так і у формі словоскладання з власне індонезійськими; 3) бере за основу морфему, яка, в свою чергу, у рідній мові (арабській) зазнала численних деривацій з утворенням похідних слів; 4) передбачає об'єднання елементів, згідно з особливостями морфології та семантики індонезійської мови.

Серед словотвірних афіксів індонезійської мови, які використовуються для утворення арабізмів, е: діеслівні («meN-», «-an», «ber-», «ter-»), іменникові («se-», «-in», «-at», «peN-an», «ke-an») та прикметникові («-i», «-iah», «-ah», «-wi»).

Наприклад, слова «khairat» (добро), «fadilat» (шляхетність) та «fasihat» (красномовство) е повністю запозиченими з арабської мови та інтегро- вані в індонезійську за допомогою приеднання суфрікса «-аt» до морфем «khair» (красивий, добрий), «fadil» (шляхетний, благородний) i «fasih» (володіти красномовством, швидко розмовляти). Тобто у цих прикладах суфікс виконуе деривативну фрункцію та спричиняе перехід прикметника у іменник.

Більшість арабських запозичень в індонезійській мові - це іменники, що позначають місце або час або іменники, які виступають сполучним словом між двома або більше взаємопов'язаними запозиченнями. Хоча є певна кількість і діеслівних запозичень з арабської. Наприклад, «рikir» (думати) з арабського «fakkara».

Також цікаво, що для уникнення нагромадження приголосних звуків в останньому складі слова, в індонезійській мові до нього додавалося закінчення «-u». Наприклад: слово «salju» (сніг) від арабського «thalj», а також «ilmu» (наука) від арабського «ilm». У деяких випадках кінцеві приголосні арабського слова в індонезійській розділяються голосним «-і-», як от у словах «fikir» або «pikir» (думати) від арабського «fikr».

Інколи одне арабське слово у ході інтеграції з індонезійською (або малайською на ранньому етапі) утворювало два похідних слова: 1) релігійний термін, що, як правило, зберігав найбільш близьку до оригінальної форму слова; 2) загальновживане слово без жодного релігійного смислового навантаження, яке зазнало численних варіативних змін. Наприклад: «fardu» (релігійний обов'язок) i «perlu» (необхідно, потребувати) - обидва слова походять від арабського «fard» (релігійний обов'язок).

Селиантичні особливості. Кожен афікс при приеднанні до основи слова, яка також може бути як дієслівною, так і іменниковою або прикметниковою, несе у собі конкретне граматичне значення або їх сукупність і виконуе певну функцію у реченні. Зокрема діеслівні афрікси мають наступні граматичні значення: 1) «виконувати певну дію, яка зазначена в основі слова»; 2) «певна дія, пов'язана з»; 3) «процес»; 4) «взаемна дія»; 5) «перебувати у певному стані»; 6) «підлягати впливу певної дії»; 7) «такий, що уже потрапив під вплив певної дії»; 8) «містити або мати»; 9) «давати певний результат»; 10) «тривала дія». Серед граматичних значень іменникових афіксів виділяють такі, як: 1) «на одному рівні, рівнозначність»; 2) «певний стан»; 3) «діяч»; 4) «спосіб виконання певної дії»; 5) «процес»; 6) «річ, предмет». У свою чергу, прикметникові афрікси в індонезійській мові мають подібні граматичні значення 3 іменниковими, зокрема: 1) «пов'язаний із чимось або стосуеться чогось»; 2) «прилад або пристрій для виконання певної діі»; 3) «діяч».

Загалом існуе три типи деформацій значення арабських запозичень: розширення значення, звуження значення та повна розбіжність. Це зумовлено використанням арабізмів в індонезійській мові в іншій сфері застосування або асиміляціею їх значення з локальними мовними реаліями.

Прикладом звуження значення може бути слово «ahad», яке в мові оригіналу означає «один», «неділя» або «перший». Натомість в індонезійській мові дане слово використовуеться лише у другому значенні - «неділя», і його ви- 
користання у двох інших значеннях не є розповсюдженим, а подекуди взагалі неприйнятним.

Розширення значення арабізмів спричинено використанням слова в індонезійській мові у більшій кількості сфрер застосування аніж у мові-джерелі. Наприклад: слово «јаhanam», що запозичене від арабського «јаhannam» (назва одного з кіл пекла), після входження в індонезійську мову набуло ще й значення «проклятий». Слово «abdi» в арабській мові означає "раб чоловічого роду або слуга», а після запозичення в індонезійську набуло додаткових значень «працівник або робітник» (покращення значення).

Частина арабських запозичень мають абсолютно інше значення ніж слово-оригінал. Прикладом може слугувати слово «јаhil», яке в арабській мові означає "дурний або нерозумний», а в індонезійській набуло значення «набридливий або поганий» (в арабській - «syirik» або «syirru»).
Іншим зразком є арабізм «hebat» (надзвичайний, грізний, неперевершений), що походить від арабського слова «haibat» (такий, 3 яким рахуються або якого бояться).

Висновки і пропозиції. Отже, входження великої кількості арабських запозичень в індонезійську мову, зумовлене тривалими культурними контактами між арабським та індонезійським народами, спричинило появу у морфології індонезійської мови нових словотвірних способів, адаптованих арабських афріксів, а також збагачення та урізноманітнення значення запозичених елементів. У результаті такого симбіозу індонезійська мова інтегрувала грунтовний пласт нових понять та реалій, цим самим збагативши свою мовну спадщину.

У подальшому у дослідженні вважаємо за доцільне зосередити увагу на вивченні особливостей вживання арабізмів у літературі та медіа.

\section{Список літератури:}

1. Большой индонезийско-русский словарь / Р. Н. Коригодский, О. Н. Кондрашкин, Б. И. Зиновьев, В. Н. Лощагин; под ред. Р. Н. Коригодского : в 2-х т. Москва : Рус. яз., 1990.

2. Демидюк Л. Русско-индонезийский словарь / Л. Демидюк, В. Погадаев. 2004.

3. Samsuri. Analisis Bahasa. Jakarta : Erlangga, 1981. P. 415.

4. Sibarani R. An Introduction to Morphology. 2002. Pp. 22-25.

5. Ruskhan A. G. Bahasa Arab dalam Bahasa Indonesia. Jakarta : Gramedia, 2007. P. 181.

6. Haugen E. V. Borrowing: An Overview. 1992. Pp. 132-135.

7. Chaer A. Pengantar Semantik Bahasa Indonesia. Jakarta : Rineka Cipta, 2009. P. 193.

8. Chaer Abdul. Morfologi Bahasa Indonesia. Jakarta : Rineka Cipta, 2005. P. 259.

9. Jones R. Loan-words in contemporary Indonesian. 1985. Pp. 78-81.

10. Badri U. Elmuna: Kamus Indonesia-Arab. Yogyakarta : UGM, 1998.

\section{References:}

1. Bolshoy indonezijsko-russkij slovar (1990) [The great Indonesian-Russian dictionary] / R. N. Korigodskij, O. N. Kondrashkin, B. I. Zinoviev, V. N. Loshhagin; pod red. R. N. Korigodskogo: v 2-kh t. Moscow : Rus. yaz.

2. Demidyuk L., Pogadaev V. (2004) Russko-indonezijskij slovar [Russian-Indonesian dictionary].

3. Samsuri (1981) Analisis Bahasa. Jakarta: Erlangga, p. 415.

4. Sibarani R. (2002) An Introduction to Morphology. Pp. 22-25.

5. Ruskhan A. G. (2007) Bahasa Arab dalam Bahasa Indonesia. Jakarta: Gramedia, p. 181.

6. Haugen E. V. (1992) Borrowing: An Overview. Pp. 132-135.

7. Chaer A. (2009) Pengantar Semantik Bahasa Indonesia. Jakarta: Rineka Cipta, p. 193.

8. Chaer A. (2005) Morfologi Bahasa Indonesia. Jakarta: Rineka Cipta, p. 259.

9. Jones R. (1985) Loan-words in contemporary Indonesian. Pp. 78-81.

10. Badri U. (1998) Elmuna: Kamus Indonesia-Arab. Yogyakarta: UGM. 